\title{
Pendampingan Bunda PAUD dalam Pembuatan Alat Permainan Edukatif (APE) Sederhana untuk Pengenalan Konsep Bangun Datar
}

\author{
Eka Susilowati $^{1 *}$, Nur Fathonah ${ }^{1}$, Erna Puji Astutik ${ }^{1}$, Susilo Hadi ${ }^{1}$, Lidya Lia Prayitno ${ }^{1}$ \\ ${ }^{1}$ Pendidikan Matematika, Universitas PGRI Adi Buana Surabaya, Jalan Dukuh Menanggal XII No.4 \\ Surabaya, Indonesia, 60234 \\ *Email: eka_s@unipasby.ac.id
}

\begin{abstract}
Abstrak
Bunda PAUD di Kecamatan Gondang memiliki kesulitan mengenalkan bangun datar pada anak usia dini. Mereka belum mengetahui APE seperti apa yang dapat digunakan untuk mengenalkan bangun datar kepada anak usia dini dan biaya untuk membuat APE-nya murah/ekonomis. Berdasarkan permasalahan tersebut, diperlukan adanya pelatihan untuk bunda PAUD dalam pembuatan APE yang sederhana namun mampu meningkatkan pemahaman anak usia dini mengenai konsep bangun datar. Tujuan pengabdian ini adalah untuk membantu bunda PAUD membuat APE yang mudah/ekonomis dibuat dalam rangka mengenalkan bangun datar ke anak usia dini sehingga dapat menembangkan motoric kasar dan halus serta kognitif pada anak usia dini. Metode yang diterapkan dalam pelatihan ini adalah metode presentasi, metode demostrasi, dan metode praktik. Metode dalam penelitian ini adalah metode penelitian kualitatif. Alat permainan edukatif yang dibuat selain mudah dibuat juga murah bahannya dari barang bekas, namun tetap aman untuk anak usia dini. Alat-alat permainan edukatif yang dihasilkan juga dapat melatih motorik halus dan kasar anak usia dini. Hasil yang dicapai dari kegiatan pengabdian pada Bunda PAUD se Kecamatan Gondang adalah para Bunda PAUD mampu membuat bahkan mengkreasikan atau mengimprovisasi alat pemainan edukatif (APE) yang diberikan dalam pelatihan dengan bahan sederhana berupa kardus. Dengan adanya bunda PAUD yang dapat mengkreasikan APE sederhana yang dibuat dari barang bekas, maka dapat mengurangi sampah dan diharapkan dapat digunakan untuk mengajarkan anak usia dini dapat dengan mudah memahami apa saja bangun datar mulai dari bentuk sehingga kemmapuan motoric dan kognitif anak usia dini tersebut meningkat. Selain itu, ternyata dengan APE yang dibuat, yaitu menara geometri dalam pelatihan ini dapat juga mengajarkan warna, dan juga membilang.
\end{abstract}

Kata kunci: APE, alat permainan edukatif, bangun datar, geometri, media pembelajaran

\begin{abstract}
PAUD mothers in Gondang sub-district find it challenging to introduce a flat shape in early childhood. They are confused about giving APE to early childhood. PAUD mothers also want APEs that they can easily make for their students at economical costs. Therefore, training is essential for PAUD mothers in making APE that is simple but able to increase the understanding of early childhood about the concept of a flat shape. The purpose of this service is to help PAUD mothers make APEs that are easy to make in order to introduce a flat shape to early childhood. The methods applied in this training are presentation method, demonstration method, and practice method. Educational game tools that are made in addition to being easily made are also cheap materials from used goods, but still safe for young children. The educational game tools produced can also train fine and gross motor skills in early childhood. The results achieved from devotional activities in PAUD mothers in Gondang District are that PAUD mothers can create or improvise educational game tools (APE) given in training. With the existence of PAUD mothers who can create simple APEs made from used goods, it can reduce waste, and we expect that early childhood can easily understand what flat shapes, color, and also count in one APE produced.
\end{abstract}

Keywords: APE, educational game tools, flat shapes, geometry, learning media 
Format Sitasi: Susilowati, E., Fathonah, N., Hadi, S., Prayitno Lia, L. (2020). Pendampingan Bunda PAUD dalam Pembuatan Alat Permainan Edukatif (APE) Sederhana untuk Pengenalan Konsep Bangun Datar. Jurnal SOLMA, 09(1), 131-142. Doi: http://dx.doi.org/10.29405/solma.v9i1.4714

Diterima: 29 Februari 2020 | Revisi: 15 April 2020 | Dipublikasikan: 30 April 2020.

\section{PENDAHULUAN}

Pendidikan anak usia dini memiliki peran yang sangat menentukan. Pada usia ini berbagai pertumbuhan dan perkembangan mulai dan sedang berlangsung seperti perkembangan fisiologis, bahasa, motorik dan kognitif (Hertayani \& Endang, 2015). Perkembangan kognitif dan motorik merupakan aspek yang harus dimiliki anak pra-sekolah. Indikator yang harus dimiliki dalam perkembangan kognitif diantaranya bentuk geometri (Atik, 2019). Dalam geometri dibahas obyek-obyek yang berhubungan dengan ruang dari berbagai dimensi (Mursalin, 2016) yang biasa kita kenal, ruang dimensi dua berupa bangun datar dan ruang dimensi tiga, berupa bangun ruang. Namun, geometri yang perlu diajarkan untuk anak usia dini adalah hanya geometri di ruang dimensi dua atau berupa bangun datar. Pengenalan bentuk geometri bangun datar untuk anak usia dini/pra-sekolah meliputi segitiga, segi empat/persegi, persegi panjang, dan lingkaran (Kurniawati, 2020). Adapun manfaat mengenal bangun datar bagi anak usia dini yakni anak akan lebih mudah dalam mengenali memahami, menghafalkan, menggambarkan, dan mendeskripsikan benda-benda di sekitarnya berdasarkan kesamaan atau perbedaan bentuknya sehingga anak dapat menyelesaikan masalah yang ada di lingkungan dalam kehidupan sehari-hari (Sholikhah, 2013). Penyebutan kotak pada bentuk persegi dan kubus terkadang membuat anak usia dini bingung. Apakah bagi mereka pigura foto dan ubin itu kotak atau persegi? Sulit kita jelaskan pada anak usia dini pentingnya penggunaan kata. Mereka belum mengunakan definisi. Bangun datar merupakan sebutan bangun-bangun dua dimensi (Astika, 2017). Anak usia dini hanya mengandalkan alat indranya untuk mencari kesaman dari suatu benda, apakah itu bangun datar atau bangun ruang tidak begitu mereka perhatikan. Kemampuan klasifikasi ini akan meningkat jika anak usia dini mendapat pengalaman matematika yang sesuai dan mudah mereka pahami dengan menggunakan penglihatan mereka.

Bunda PAUD di Kecamatan Gondang ini kesulitan mengenai bagaimana cara mengenalkan anak usia dini tentang bangun datar. Para orang tua sebenarnya juga cukup sulit untuk membimbing anak usia dini karena ketertarikan anak yang bosan jika media belajar mereka hanya buku (Sundari \& Wahyuningsih, 2015). Mereka membutuhkan cara yang menarik untuk dapat mengajarkan anak usia dini belajar dalam hal ini mengenal bangun 
datar, namun tidak terasa belajar, seperti bermain. Bagi sebagian orang tua dan bunda PAUD, mendampingi anak usia dini saat bermain atau belajar bukanlah hal ringan. Apalagi bila harus mengaitkan dengan tujuan dan manfaat dari setiap kegiatan bermain anak sambil belajar (Fayeldi \& Ferdiani, 2016). Dalam pengenalan konsep geometri, dapat dikenalkan orang tua atau bunda PAUD dengan barang sekitar (Yuni \& Dewi, 2019) seperti menunjukkan buku, tutup gelas, kotak pensil, dan lain-lain., namun kurang menarik bagi anak usia dini. Untuk meningkatkan semangat anak usia dini belajar mengenal dan mengingat, dapat dengan menggunakan alat permainan edukatif (APE) yang dapat dibuat sendiri dengan barang yang murah atau bekas. Dengan demikian, anak tidak terasa belajar, karena sambil bermain. Bermain merupakan aktifitas yang dapat mengembangkan kemampuan kognitif anak. Selain kegiatan yang menyenangkan, bermain dapat menghasilkan suatu karya dan pengalaman baru bagi anak (Yuni \& Dewi, 2019). Melalui bermain, anak-anak membangun pengetahuan penting yang mencakup banyak domain perkembangan seperti bahasa dan matematika (Koesmadi, 2019). Penyampaian materi dalam mengembangkan kognitif atau intelektual harus menggunakan tahap permainan. Berdasarkan (Veronica, 2019)., permainan yang dapat mengembangkan aspek kognitif adalah puzzle geometri Berbagai jenis alat permainan edukatif dapat menjadi alternatif untuk meningkatkan atau menstimulus kemampuan anak, seperti mengenalkan geometri bangun datar dapat menggunakan puzzle geometri sebagai alat permainan edukatifnya.

Saat ini kebanyakan bunda PAUD memberikan materi di sekolah masih menggunakan metode pembelajaran dengan media buku panduan atau memberikan contoh dengan barang yang ada di sekolah (Rozi \& Khomsatun, 2019). Salah satu materi yang dikenalkan bunda PAUD adalah bangun datar, yang memang lebih mudah untuk diajarkan kepada anak usia dini dibandingkan bangun ruang. Hal tersebut kurang cocok apalagi untuk mengenalkan bangun datar. Anak usia dini akan cenderung senang bermain daripada menghadap buku sehingga perlu diciptakan alat permainan edukatif yang memfasilitasi anak belajar sambil bermain. Pada artikel (Qhadafhi, 2018), telah diperkenalkan alat pengenalan bentuk geometri anak usia dini berbasis mikrokontroler.. Pada artikel (Mi \& Sulaiman, 2019), menggunakan media origami yang diterapkan untuk mengenalkan konsep bangun datar pada siswa jenjang sekolah dasar. Namun, media ini tidak cocok jika diterapkan pada anak usia dini. Pembuatan media pembelajaran untuk anak usia dini merupakan kegiatan yang memerlukan kemampuan yang memadai dan membutuhkan persyaratan tertentu yaitu pengetahuan mengenai perkembangan anak dan keterampilan kreatif untuk membuat media 
sehingga alat permainan edukatif (APE) betul-betul efektif dalam mengembangkan aspekaspek perkembangan anak usia dini (Atik, 2019) di antaranya aspek motoric dan kognitif. Aspek kognitif ini dikatakan penting karena akan berhubungan dengan kreativitas dan imajinasi anak untuk menyesuaikan diri dengan lingkungan (Yulistia, 2018). Pada artikel (Yulistia, 2018) ini, hanya dibahas bagaimana mengembangkan kemampuan kognitif melalui media bahan kardus bentuk geometri. Pada artikel ini dibahas mengenai bagaimana bunda PAUD ini dapat membuat APE yang dapat mengembangkan kemampuan tidak hanya kognittif tetapi juga motoric. Oleh karena itu, diadakan pelatihan pada bunda PAUD membuat APE namun lebih sederhana dengan bahan bekas yang ada di lingkungan sekitar, murah, dan mudah diperoleh, semisal kardus, kertas dan roti dan cara memanfaatkannya dalam pembelajaran anak usia dini sehingga menunjang perkembangan kemampuan tidak hanya kognitif tetapi juga motoric.

\section{MASALAH}

Fakta lapangan menunjukkan bahwa media pembelajaran edukatif di Pos PAUD Terpadu (PPT) di wilayah Kecamatan Gondang Kabupaten Mojokerto kurang memadai. Survei dilakukan oleh salah satu dosen, Ibu Eka Susilowati, S.Si. M.Sc. di Kecamatan Gondang pada tanggal 10 - 13 Januari 2020 dengan mengunjungi salah satu PAUD dan melakukan wawancara dengan Bunda PAUD. Selain itu, Bunda PAUD di Kecamatan Gondang merasa kesulitan mengenalkan bangun datar pada anak usia dini. Kesulitan bunda PAUD lebih pada seperti apa APE yang harus dibuat, sederhana, ekonomis namun nantinya APE tersebut dapat mencapai tujuan dapat mengembangkan kemampuan kognitif dan motoric anak usia dini. Bunda-bunda PAUD menginginkan APE yang dapat dibuat dengan mudah untuk anak didiknya. Diperlukan sosialisasi tentang alat permainan edukatif bagi anak usia dini dan juga penting pelatihan yang dapat mengatasi masalah tersebut, misalnya dengan menciptakan alat permainan edukatif dengan konsep dasar matematika yaitu konsep bangun datar. Rumusan masalah pada kegiatan pengabdian ini adalah membantu bunda PAUD membuat APE yang mudah dari bahan sederhana, sehingga anak usia dini lebih mudah mengenal bangun datar.

Tantangan pada pengabdian kepada masyarakat ini adalah alat permainan edukatif (APE) seperti apa yang akan dibuat dengan memanfaatkan lingkungan sekitar misalnya dengan memanfaatkan limbah serta ramah lingkungan. Bahan APE-nya murah dan mudah didapat serta dibuat dengan bahan bekas sehingga mengurangi limbah yang ada dan dapat bermanfaat mejadi media pembelajaran. Hal ini dikarenakan agar bunda PAUD bisa 
mempraktekkannya pada saat pembelajaran sambil bermain untuk anak usia dini dengan dana yang terbatas. Akhirnya, dengan adanya diskusi dan melihat beberapa referensi di youtube, instagram, dan berdiskusi dengan salah satu dosen PAUD, didapat beberapa alat permainan edukatif yang murah bahkan gratis karena yang digunakan kardus, mudah dibuat, dan mudah diterapkan. Alat permainan edukatif yang diciptakan mudah dibuat sebagai pertimbangan, agar dapat juga dipratekkan pada saat pelatihan yang waktunya terbatas.

\section{METODE PELAKSANAAN}

Metode yang digunakan dalam penelitian ini adalah penelitian kualitatif. Metode yang digunakan dalam kegiatan Pengabdian pada Masyarakat yang subtemanya konsep bangun datar pada AUD melalui Alat Permainan Edukatif (APE) ini adalah:

1. Metode ceramah/presentasi untuk sosialisasi dalam pengenalan alat permainan edukatif, manfaat alat permainan edukatif, macam-macam bangun datar yang diperkenalkan, yang dihadiri oleh Bunda PAUD se-Kecamatan Gondang.

2. Metode demonstrasi, untuk menunjukkan cara pembuatan dan penggunaan Alat Permainan Edukatif (APE) kepada Bunda PAUD.

3. Metode praktek, untuk mengetahui seberapa besar pemahaman bunda PAUD setelah didemonstrasikan. Bunda PAUD diminta untuk membuat salah dua APE dari empat yang didemontrasikan.

Pelaksanaan program ini melibatkan mahasiswa untuk membantu jalannya acara, seperti MC, dokumentasi, secretariat, dan konsumsi, dan proses praktik pembuatan APE oleh bunda-bunda PAUD. Kegiatan tanya jawab dilakukan bersamaan dengan presentasi dari pemateri. Saat praktek, peserta dan pemateri langsung mengadakan diskusi terhadap proses pembuatan APE dan pengalaman peserta mengenai masalah pengenalan konsep bangun datar terhadap anak usia dini yang telah dilakukan. Pelaksanaan pengabdian pada masyarakat dilakukan dengan langkah-langkah sebagai berikut:

1. Survey Lapangan

Survey lapangan telah dilaksanakan dua minggu sebelum kegiatan pengabdian pada masyarakat dilaksanakan. Survey fasilitas APE yang sudah ada di beberapa PAUD Kecamatan Gondang. Alat permainan edukatif yang dimiliki masih terbatas, apalagi untuk mengenalkan anak usia dini konsep bangun datar. Survey lapangan ini bertujuan untuk meninjau lokasi pelaksanaan, mendata jumlah bunda PAUD yang akan diundang sejumlah 35 orang dan berkoordinasi dengan pihak Kecamatan Gondang yang akan dijadikan lokasi dan waktu pelaksanaan kegiatan. 
2. Penyusunan Proposal

Proposal disusun setelah mendapatkan gambaran permasalahan mitra yang akan diberdayakan dengan bekerja sama dengan mitra pendukung program pengabdian pada masyarakat dan pihak Kecamatan Gondang.

3. Pengurusan Perijinan

Pihak Prodi Pendidikan Matematika kemudian melakukan perijinan, baik kepada pihak Kecamatan Gondang.

4. Sosialisasi dan Pelatihan Kelompok Sasaran

Kegiatan sosialisasi dan pelatihan kelompok sasaran menjadi bagian utuh dari program Pengabdian pada Masyarakat dosen yang dilaksanakan secara fleksibel sesuai dengan jadwal yang telah ditetapkan bersama dengan berbagai pihak terkait, baik pihak Kecamatan Gondang maupun Bunda PAUD di Kecamatan Gondang. Materi yang disajikan ada lima bahasan. Berikut daftar materi dan pemateri yang telah terlaksana dalam pengabdian kali ini.

Tabel 1. Daftar Kegiatan Pengabdian

\begin{tabular}{|c|c|c|}
\hline Materi & Pemateri & Waktu \\
\hline $\begin{array}{l}\text { Matematika tentang Bentuk } \\
\text { Geometri untuk Anak Usia } \\
\text { Dini }\end{array}$ & Eka Susilowati, S.Si., M.Sc. & $\begin{array}{l}\text { 04 Februari } 2020 \\
\text { Pukul: } 08.30-09.15\end{array}$ \\
\hline $\begin{array}{l}\text { Alat permainan edukatif } \\
\text { secara umum }\end{array}$ & Nur Fathonah, S.Pd., M.Pd. & $\begin{array}{l}\text { 04 Februari } 2020 \\
\text { Pukul: } 09.15-10.00\end{array}$ \\
\hline $\begin{array}{l}\text { Motorik Kasar dan Halus } \\
\text { Anak Usia Dini }\end{array}$ & Drs. Susilo Hadi, M.Pd. & $\begin{array}{l}\text { 04 Februari } 2020 \\
\text { Pukul: } 10.00-12.00\end{array}$ \\
\hline Workshop APE motorik halus & $\begin{array}{l}\text { Erna Puji Astutik, S.Si., } \\
\text { M.Pd., M.Sc. }\end{array}$ & $\begin{array}{l}21 \text { Maret } 2020 \\
\text { Pukul: } 09.00-12.00\end{array}$ \\
\hline Workshop APE motorik kasar & $\begin{array}{l}\text { Lidya Lia Prayitno, S.Pd., } \\
\text { M.Pd. }\end{array}$ & $\begin{array}{l}27 \text { Maret } 2020 \\
\text { Pukul: } 09.00-12.00\end{array}$ \\
\hline
\end{tabular}

5. Pendampingan Operasional

Pendampingan operasional, baik dari tim pengabdi menjadi pendukung di dalam proses kelancaran terlaksananya kegiatan Pengabdian pada Masyarakat guna memfasilitasi berbagai bentuk sarana dan prasarana yang menunjang pelaksanaan pengenalan, pelatihan membuat dan praktek menggunakan Alat Permainan Edukatif (APE) bagi Bunda PAUD di Kecamatan Gondang. Pendampingan diperlukan karena bunda PAUD ditugaskan membuat dua dari empat APE yang dicontohkan. Tim 
pengabdi memandu, memberikan solusi ketika bunda PAUD mengalami kesulitan selama praktek pembuatan APE berlangsung.

6. Evaluasi dan penyempuranaan karya Alat Permainan Edukatif oleh tim pengabdi

Pada akhir pelatihan, APE yang dibuat oleh bunda PAUD dikumpulkan dan dikumpulkan dan dinilai oleh tim pengabdi. Setelah itu, diberikan masukkan untuk penyempurnaan APE dan dikembalikan ke bunda PAUD lagi agar dapat digunakan dalam pembelajaran anak usia dini.

7. Refleksi dan penutupan

Pada akhir kegiatan, bunda PAUD dan tim pengabdi melakukan refleksi terhadap hasil APE. Bunda PAUD mendapatkan koreksi dan evaluasi terhadap APE yang telah dibuat. Bunda PAUD juga memberikan evaluasi dan masukan terhadap pelatihan ini. Tim pengabdi menutup acara dan memberikan pesan pada bunda PAUD untuk dapat menerapkan alat permainan edukatif yang dibuat pada pembelajaran anak usia dini sehingga dapat memperbaiki pembelajaran anak usia dini yang telah ada. Tim pengabdi dan bunda PAUD yang hadir berharap pelatihan dapat dilanjutkan dan dihadiri lebih banyak bunda PAUD lagi.

8. Pembuatan Laporan Pengabdian pada Masyarakat

Pembuatan laporan merupakan tahap terakhir yang memaparkan tentang segala bentuk kegiatan melalui narasi dan dokumentasi kegiatan Pengabdian pada Masyarakat yang sekaligus sebagai laporan pertanggungjawaban pelaksanaan kegiatan dari awal hingga akhir.

\section{HASIL DAN PEMBAHASAN}

Pelatihan ini memberikan beberapa APE yang dapat digunakan untuk mengembangkan media pembelajaran yang dapat meningkatkan ketrampilan motoric kasar dan halus, serta kognitif anak usia dini. Kegiatan PPM ini, bangun datar yang diajarkan untuk anak usia dini kepada Bunda PAUD melalui APE adalah persegi, lingkaran, segitiga. Hal tersebut dikarenakan anak usia dini diajarkan bangun datar yang sederhana dan bangun datar yang banyak mereka temui di kehidupan sehari-hari. Alat permainan edukatif untuk motoric halus yang dihasilkan dalam kegiatan pengabdian ini adalah roti geometri. Alat permainan edukatif untuk motoric kasar adalah bangun tumpuk, menara geometri, dan puzzle geometri. 


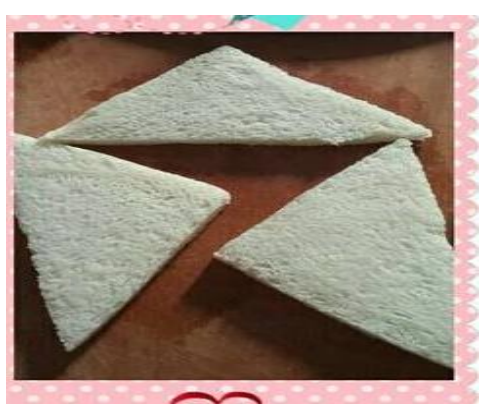

Gambar 1. Roti Geometri

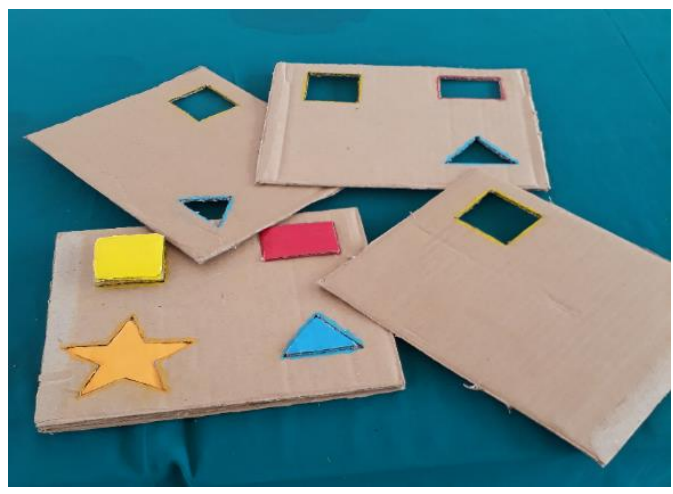

Gambar 3. Puzle Geometri

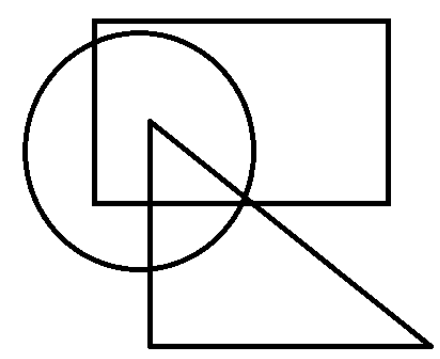

Gambar 2. Bangun Tumpuk

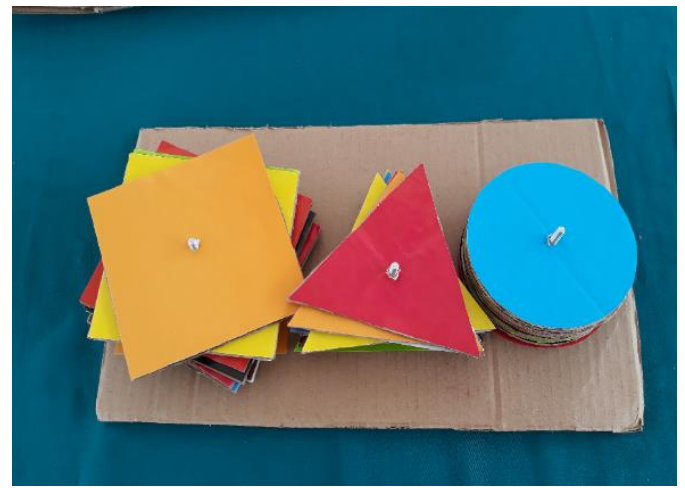

Gambar 4. Menara Geometri

Dalam pembuatan APE ini juga diharapkan selain dapat mengembangkan aspek motoric anak, juga dapat mengembangkan aspek kogniif pada anak. Kognitif adalah suatu proses berpikir dan berhubungan dengan tingkat kecerdasan yang sebagian besar ditentukan oleh manipulasi dan interaksi aktif anak dengan lingkungan yaitu kemampuan untuk menghubungkan, menilai dan mempertimbangkan suatu kejadian atau peristiwa (Yulistia, 2018). Seperti yang dijelaskan di atas, aspek kognitif ini penting karena akan berhubungan dengan kreatifitas dan imajinasi anak untuk menyesu aikan diri dengan lingkungan. Kemampuan dasar kognitif anak yang berada pada fase praoperasional (2-7 tahun) diwarnai oleh perkembangan fungsi kemampuan berpikir secara simbolik, hal ini berarti walaupun benda aslinya tidak ada, anak akan dapat membayangkan bentuk benda itu sendiri di dalam pikirannya (Yulistia, 2018). Anak dapat diajarkan ketiga bangun sederhana itu dan dengan mudah kita dapar kaitkan dengan benda - benda yang ada di lingkungan untuk dapat ditunjukkan kepada anak usia dini sehingga mereka dapat mudah mengenali dan mengidentifikasi bangun datar tersebut. Misalnya, anak diberikan tutup gelas sebagai symbol lingkaran, buku sebagai symbol persegi, roti tawar segitiga sebagai symbol segitiga. Hal tersebut berakibat dapat menjadi jalan untuk mengembangkan aspek kognitifnya. Alat 
Permainan Edukatif yang dihasilkan pun juga berhubungan dengan kreatifitas. Anak dapat diajarkan membuat bangun datar dari kardus seperti pada menara geometri namun dengan pilihan warna dari mereka sehingga kreatifitas merekapun jadi berkembang.

Berdasarkan diskusi yang dilaksanakan setelah pemaparan materi, banyak bunda PAUD yang antusias mengikuti hingga selesai dan mampu membuat APE yang diberikan tim pengabdi. Alat permainan yang dihasilkan berbeda dengan alat permainan edukatif yang dihasilkan pada artikel yang ditulis (Kurniawati, 2020) dan (Atik, 2019) namun bahannya sama-sama kardus. Menurut hasil pratiknya juga dapat dilihat bahwa para bunda PAUD memiliki kreatifitas dalam mengimprovisasi APE yang dicontohkan tim pengabdi. Para bunda PAUD juga mampu memahami cara penggunaan APE yang diberikan untuk menunjang proses pembelajaran anak usia dini sambil bermain. Alat permainan edukatif yang diajarkan awalnya hanya digunakan untuk mengenalkan bangun datar pada anak usia dini. Namun, ada bunda PAUD yang mengusulkan bahwa APE berupa puzzle geometrid dan menara geometri juga dapat digunakan untuk menghitung.

Tim pengabdi pada saat presentasi di lokasi juga memiliki ide bahwa alat permainan edukatif yang dicontohkan, seperti menara geometri, bangun tumpuk dan puzzle geometri mampu membuat anak mengenal warna. Dengan demikian, alat permainan edukatif yang dicontohkan tim pengabdi bisa dikatakan multi fungsi, karena satu APE dapat digunakan untuk mengenalkan konsep bangun datar, membilang, dan warna. Alat Permainan Edukatif yang dibuat pengabdi ini yang kemudian ditularkan kepada Bunda PAUD di Kecamatan Gondang ini, dapat digunakan untuk mengembangkan aspek motoric dan kognitif anak usia dini. Hal tersebut sesuai dengan apa yang dikemukakan Piaget bahwa anak usia 3-6 tahun anak berada pada masa praoperasional. Pada masa ini, anak sudah dapat berpikir dalam menggunakan symbol, mengklasifikasi dan memahami angka. Ketiga hal tersebut sudah tercover oleh APE roti geometri untuk symbol mana segitiga, mana persegi, mana lingkaran; bangun tumpuk untuk mengklasifikasi mana bentuk bangun datar segitiga, persegi, dan lingkaran ketika mereka diminta mewarnai bangun yang disebut oleh Bunda PAUD; menara geometri untuk mengklasifikasi dan memahami angka, serta puzzle geometri untuk mengklasifikasi besar kecil agar dapat ditumpuk dan memahami angka dengan menghitung bangun datar pada tiap keping puzzlenya.

Para peserta kegiatan juga berharap jika nantinya kegiatan ini selalu berkesinambungan karena kegiatan yang dilakukan oleh Tim Pengabdi Dosen Pendidikan Matematika Universitas PGRI Adi Buana Surabaya adalah salah satu kegiatan yang sangat 
menunjang dalam perbaikan kualitas keterampilan yang dimiliki Bunda PAUD sehingga menunjang iklim pembelajaran AUD yang lebih kondusif. Apalagi bahan APE yang diajarkan pemateri mudah didapat, murah dan mudah dibuatnya.

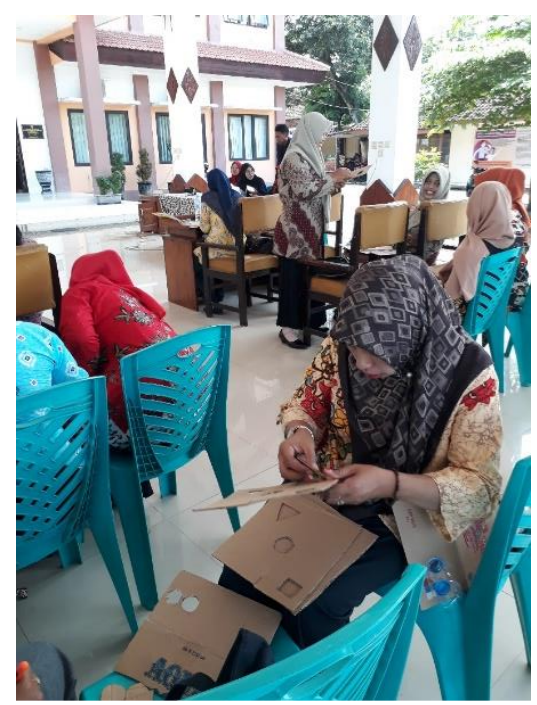

Gambar 5. Kondisi saat pelatihan

Kendala yang dihadapi saat pelaksanaan Program Pengabdian kepada Masyarakat oleh Tim Dosen Pendidikan Matematika Universitas PGRI Adi Buana Surabaya adalah ruangan yang tersedia di Kecamatan Gondang luas, namun kurang meja pada setiap kursi, sehingga ketika peserta mempratekkan membuat APE yang diberikan pemateri, agak kesulitan dalam menggambar, memotong dengan cutter dan mewarnai gambar. Selain itu, bahan kertas lipat yang dibagikan terbatas, serta tidak disediakan crayon atau pensil warna yang memadai seluruh peserta.

\section{KESIMPULAN}

Bunda PAUD sangat antusias dalam mengikuti kegiatan ini. Antusias peserta dapat terlihat dari kehadiran jumlah peserta sebanyak 28 peserta dari 35 peserta yang diundang di setiap kegiatan. Selain itu, antusias peserta dapat dilihat dari keaktifan mereka dalam mengikuti kegiatan PPM ketika membuat APE. Banyak muncul kreatifitas bunda PAUD dalam mengimprovisasi APE yang diajarkan pemateri. Banyak muncul kreatifitas bunda PAUD dalam mengimprovisasi APE yang diajarkan pemateri. Alat permainan edukatif yang dibuat pun multi fungsi karena dapat memperkenalkan anak usia dini bangun datar saja, namun dapat juga memperkenalkan warna dan bilangan pada APE menara geometri. Apabila ditilik kembali, lebih dominan pada pengenalan bangun datar karena APE yang dibuat sebagian besar menuntun anak untuk mengenal bagaimana bentuk bangun datar dari symbol yang dibuat pada APE roti geometri an bangun tumpuk, serta mengidentifikasi atau 
mengklasifikasikannya dengan memilih bentuk yang sama seperti bangun datar yang kita minta pada APE menara geometri dan puzzle geometri sehingga aspek motoric dan kognitifnya berkembang. Para bunda PAUD mengharapkan dapat diselenggarakan kegiatan serupa namun dengan barang bekas lain yang dapat mengenalkan matematika pada anak usia dini.

\section{UCAPAN TERIMA KASIH}

Ucapan terima kasih terutama ditujukan kepada Lembaga Penelitian Pengembangan dan Pengabdian kepada Masyarakat (LPPM) Universitas PGRI Adi Buana Surabaya sebagai pemberi dana kegiatan pengabdian ini. Ucapan terima kasih juga disampaikan kepada pihakpihak yang membantu pelaksanaan kegiatan, seperti camat kecamatan Gondang beserta stafnya yang telah memberikan izin hingga kegiatan ini bisa terlaksana.

\section{DAFTAR PUSTAKA}

Astika, J. C. (2017). ARTIKEL APLIKASI PENGENALAN BANGUN DATAR UNTUK PENDIDIKAN ANAK USIA DINI ( PAUD ) SURAT PERNYATAAN ARTIKEL SKRIPSI TAHUN 2016 / 2017. 01(03).

Atik, K. M. (2019). Pelatihan Pembuatan Dan Pemanfaatan Media Pembelajaran Pada Guru Di Ppt Nur Insani Surabaya. Journal Community Development and Society, 1(2), 89-98. https://doi.org/10.25139/cds.v1i2.1810

Fayeldi, T., I. D, R. N., \& Ferdiani, R. D. (2016). Pengenalan Macam-Macam Bangun Ruang Dengan Media Manipulatif Matematika Sederhana Pada Anak Paud.

Hertayani, L., Endang, B., \& Astuti, I. (2015). Peningkatan Kemampuan Mengenal Bangun Datar Melalui Media Geometri Pada Usia 5-6 Tahun. (58), 1-13.

Koesmadi, D. P. (2019). PENGARUH CONSTRUCTIVE PLAY TERHADAP KEMAMPUAN PENGENALAN GEOMETRI DAN KLASIFIKASI PADA ANAK PENDAHULUAN Pada masa usia golden age merupakan masa dimana anak dalam tahap pertumbuhan dan perkembangan yang paling pesat, baik fisik maupun mental. Selain per.

Kurniawati, N. (2020). Pengembangan mengenal bentuk geometri melalui media bahan alam kardus bekas di paud. 3(1), 28-33.

Mi, V. I., \& Sulaiman, D. (2019). secara harfiah berarti “ Perantara " atau "Penyalur ". Hal ini bermaksud bahwa. 2(1), 55-66.

Mursalin. (2016). Pembelajaran Geometri Bidang Datar Di Sekolah Dasar Berorientasi Teori Belajar Piaget. Jurnal Dikma, 4(2), 250-258.

Qhadafhi, M. (2018). Alat Pengenalan Bentuk Bangun Geometri Berbasis Mikrokontroler Untuk Anak Usia Dini. 12(2), 186-196.

Rozi, F., \& Khomsatun, K. (2019). Rancang Bangun Game Edukasi Pengenalan Warna Untuk Pendidikan Anak Usia Dini Menggunakan Adobe Flash Berbasis Android. JIPI (Jurnal Ilmiah Penelitian Dan Pembelajaran Informatika), 4(1), 12. https://doi.org/10.29100/jipi.v4i1.781

Sholikhah, M. (2013). Bermain Kotak Bentuk Geometri Terhadap Hasil Belajar Matematika. Jurnal 
Pendidikan Khusus, 53(9), 1689-1699. https://doi.org/10.1017/CBO9781107415324.004

Sundari, S., \& Wahyuningsih, D. (2015). Aplikasi Pembelajaran Pengenalan Huruf, Angka, Warna dan Bentuk Bangun Datar Pada Siswa Kelas 1 SDN 5 Parittiga Berbasis Android. Jurnal Sisfokom (Sistem Informasi Dan Komputer), 4(1), 56. https://doi.org/10.32736/sisfokom.v4i1.204

Veronica, N., \& Lutifiah. (2019). Peningkatan perkembangan kognitif melalui penggunaan puzzle pada anak tk. 19(3), 1-11.

Yulistia, D. (2018). Mengembangkan Kemampuan Kognitif Melalui Media Bahan Kardus Bentuk Geometri di Taman Kanak-Kanak Negeri Sekincau Lampung Barat. Universitas Islam Negeri Raden Intan Lampung.

Yuni, E., \& Dewi, P. (2019). Kemampuan Mengenal Bentuk Geometri Melalui Permainan Balok Anak Usia Dini. Journal on Early Childhood Education Research (JOECHER), 1(1), 34-48. 